\title{
Revisiting Green Marketing Implementation in Halal Cosmetic Brands
}

\author{
Ika Diyah Candra Arifah
}

Department of Management, Faculty of Economics, Universitas Negeri Surabaya Jalan Ketintang, Surabaya 60231, Indonesia

\begin{abstract}
The growing green consumer who selecting products that socially and environmentally ethical products, encourages cosmetics producers in Indonesia to produce more environmentally friendly product in terms of materials, ingredients, packaging, and even the strategy to promote it. As this market segment continues to grow and develop, cosmetics manufacturers are required to be more competitive by applying green marketing values. Therefore, this study aims to investigate how halal cosmetic brands applying green marketing based on the concept of green marketing strategy and Islamic Marketing Ethics (IME). This case study uses a qualitative research approach that selecting four top halal cosmetic brands that marketed in Indonesia. Data was analyzed by data triangulation and method triangulation approach and presented in inductive summary. The results of the study concluded that among the top four halal cosmetics brands studied, two brands had implemented the concept of green marketing strategy and implementation comprehensively (shaded green and extreme green), while the other two brands applied lean green and defensive marketing strategy and implementation. The implication of this research is to provide suggestion to managerial marketing about how to create a more captivating halal products for all customers. The novelty of research proposes how is the level of Indonesian halal cosmetic brands green strategy that applying Islamic Marketing Ethics (IME).
\end{abstract}

Keywords: Green Marketing, Indonesia, Halal Cosmetic Brand

Paper type: Research paper

Corresponding author: ikaarifah@unesa.ac.id

Received: April 01, 2020; Accepted: Juny 21, 2020; Published: July 01, 2020

\section{Cite this document:}

Arifah, I. D. C., (2020). Revisiting Green Marketing Implementation in Halal Cosmetic Brands. Al-Uqud: Journal of Islamic Economics, 4(2), 285-306. doi: http://dx.doi.org/10.26740/al-uqud.v4n2.p285-306

Copyright () 2020, Al-Uqud: Journal of Islamic Economics http://journal.unesa.ac.id/index.php/jie 


\begin{abstract}
Abstrak: Semakin banyaknya konsumen hijau yang memilih produk yang etis secara sosial dan lingkungan, mendorong produsen kosmetik di Indonesia untuk lebih banyak menghasilkan produk yang ramah lingkungan baik dari segi bahan, bahan, kemasan, bahkan strategi promosi. Sejalan dengan segmen pasar ini yang terus tumbuh dan berkembang, produsen kosmetik dituntut untuk semakin kompetitif dengan menerapkan nilai-nilai green marketing. Oleh karena itu, penelitian ini bertujuan untuk mengetahui bagaimana brand kosmetik halal menerapkan green marketing berdasarkan konsep green marketing strategy dan Islamic Marketing Ethics (IME). Studi kasus ini menggunakan pendekatan penelitian kualitatif dengan memilih empat merek kosmetik halal dengan market share terbesar di Indonesia. Data dianalisis dengan triangulasi data dan triangulasi metode dan disajikan dalam paparan induktif. Hasil penelitian menyimpulkan bahwa dari empat merek kosmetik halal yang diteliti, dua merek telah menerapkan konsep green marketing strategy dan implementasi secara komprehensif (shaded green dan extreme green), sedangkan dua merek lainnya menerapkan strategi lean green dan defensive marketing. Implikasi dari penelitian ini adalah memberikan saran kepada pemasaran manajerial tentang bagaimana menciptakan produk halal yang atraktif bagi seluruh pelanggan. Kebaruan penelitian ini mengusulkan bagaimana level strategi hijau merek kosmetik halal Indonesia yang menerapkan Islamic Marketing Ethics (IME).
\end{abstract}

Kata Kunci: Green Marketing, Indonesia, Merek Kosmetik Halal

\title{
INTRODUCTION
}

Islam emphasizes the existence of vertical and horizontal dimensions in all fields of life, including economics which includes marketing. The vertical dimension of Islamic economics is the transcendence of the ownership of wealth obtained through working as a realization of religious obligations (Yusoff, 2019). Therefore, every effort to build economic activity is always inseparable from the search for divine pleasure. Meanwhile, the horizontal dimension is the social meaning in work and the progress of economic activities, both in terms of business and in relation to social obligations to others. In this regard, Ya'qub (2003) mentions four types of human responsibility, including in work or economic activities. First, human behaviour is encouraged to not conflict with the rules or provisions of His laws. Second, institutional responsibility which conveys the responsibility of human towards their superiors and parties who give them authority in organization. Third, legal responsibility. This usually relates to a person's willingness to take responsibility before the court. Fourth, social responsibility, that is, moral relations with the community. That is, people who do an action, morally must be responsible for his actions, that it is not a despicable act in the eyes of the community and can harm the community.

For marketers, Islam encourages business and marketing activities but does not cheat (Abdullah, 2008). For this, the marketer must be responsible for all his items, based on the following verses: (Al-Quran, 21: 47). "We will set the scale of justice for Judgment Day, so that not a single soul will be treated unfairly, and if there is (no more than) the weight of a mustard seed, we will carry it (count) and it is enough for us to calculate". Furthermore (Al-Qur'an, 83: 1-4) also mentions "Woe to those who deal with deception (those who give less in size and weight). And when they have to give by size or weight to men, give less than they should. Don't they

Copyright () 2020, Al-Uqud: Journal of Islamic Economics http://journal.unesa.ac.id/index.php/jie 
think they will be called to take responsibility "The Muslim marketer must be honest and take full responsibility for their product. Muslim entrepreneurs are responsible for protecting the interests of their employees, business partners, consumers, suppliers, and society in general in addition to aiming for the main purpose of generating profits (Susanti, 2014). Entrepreneurs are expected to uphold the virtues of justice, magnanimity, cooperation, doing-good and avoiding all mistakes, trust, and non-retaliation (Saeed et al. 2001). The words of the Prophet (peace be upon him) which are a stark reminder still apply to producers as narrated in Sahih Bukhari. First, their marketing must avoid selling doubtful items (Hadith Al Bukhari, no. 2055). Moreover, marketers must be honest in buying and selling (Hadith Al Bukhari, no. 2126); avoid fraudulent activities (Hadith Al Bukhari, no. 2117) and finally, marketers must avoid the element of speculation (gharar) (Hadith Al Bukhari, no. 2143).

Furthermore, the Islamic perspective on the environment rests on the belief that Allah (swt) is the Creator and Preserver of the universe. Everything created by God has a just purpose that must be fulfilled. In addition, not all factors of production are permanent here (some cannot be renewed). The Holy Koran, explaining this, says: (Al-Quran: 46: 3) "We did not create the heavens and the earth and all of them but for a just purpose, and for a specified period of time: but those who refused Faith turns away from where they are warned". Therefore, Islam has a rich contents in highlighting the importance of environmental protection and preservation of natural resources. Exploitation of certain natural resources is directly related to the responsibility and maintenance of these resources ( $\underline{\mathrm{Ahmad}}$, 1995).

A gainful marketer, according to the Qur'an, meets three elements: a) Knowing the best investment; b) Make sound judgments; c) Following the right behavior based on the preferences of what is al-awam (good) and halal (halal) compared to what is khabith (bad) and haram (breaking the law) as a guide for proof of good judgment.Islamic Marketing Ethics (IME) combines the principles of value maximization with the principles of fairness and justice for welfare (Hassan et al. $\underline{2015}$ ). Islamic marketing ethics (Hassan et al, 2015) differ from secular approaches in several ways. First, they are not relative but absolute in their terms because they are based on the Qur'anic injunctions and do not leave room for ambiguous interpretations by marketing executives in accordance with their individual desires and desires. The second important difference is the transcendental aspect of the absolute and non-soft nature. Third, the Islamic approach emphasizes the maximization of values in the view of the greater good of society than selfish efforts to maximize profits. Islamic Marketing Ethics (IME) that combines the principles of value maximization with the principles of equity and justice for the welfare has the characteristic of of green marketing. Although it is not mentioned specifically that green marketing concept embodied in Islamic Marketing Ethics. Nevertheless, Islamic Marketing Ethics has the similar value of green marketing that requires fair and justice practice not only between the producer and concumer but also from all the stakeholder to be resposible to the society and environtment (Hassan et al. $\underline{2015}$ ). 
Furthermore, there were some previous research related to the implementation of green marketing in cosmetics and skin care companies, such as Abzari et al. (2013) which revealed significant and positive relation between green marketing mix and market share increase of skin care products. Islam \& Chandrasekaran (2013) also added that halal (skincare) provides a great business opportunity in the middle of market saturation and declining global market. Therefore, halal certification is a part of marketing idea for green brand that naturally shariah compliant. Meanwhile, Osman et al. (2016) was initially studied about the implementation of green marketing mix in personel care (including halal cosmetic brand) in Malaysia stated that the implementation of green marketing mix is significantly influenced by manager's awareness. Chin et al. (2018) investigation on consumer behaviour intention toward green skincare products also stated that pro-environmental behaviour model influence about $62 \%$ on purchase intention. Nevertheless, Saxena (2015) added that green skin care companies should be aware about false and partially justified green claims because when consumers reveal it, it will create adverse eefect on green projects and true effort of companies. Based on Bukhari et al. (2019) consider the green strategy of company and Islam as two sides in the same coin. Based on the self-congruity theory, Bukhari et al. (2019) stated that Muslim consumers will tend to choose brands that are congruent with their personality traits and beliefs. As Islam teaches about the importance of maintaining sustainability as stated in the Qur'an (Al Qur'an: Al Ma'eda: 64; $\mathrm{Al}$ A'raf: 7, 21 \& 85; Al Qasas: 77). These verses prohibit environmental corruption, for example industrial pollution, environmental destruction and reckless natural resources exploitation. This is in line with the Environmental, Social and Governance applied by green companies, for example green banks in this study. This is what then inspired this research to identify how green marketing strategy is consistent with Islamic Markething Ethics, by examining the application of green marketing in halal cosmetic brands.

Therefore, this case study focuses on investigating how Indonesian halal cosmetic brands that applying Islamic Marketing Ethics (IME) coincided with green marketing strategy based on Grinsberg \& Bloom (2014) theory. The novelty of research proposes about discussion the similiar principles of green marketing and Islamic marketing and how Islamic marketing practitioners might use it for promoting their products to non-Muslim potential consumers (especially green consumers).

\section{Islamic Perspective on Ethical Marketing}

Prosperity or welfare (economic profit) is a goal to be achieved by a person or company in carrying out a socially responsible business or economic activity. However, these variables cannot be separated from other variables namely ethical behavior. Ethical behavior is the direction one must take in carrying out a welfare goal by implementing the rules and norms that practiced in the community. Regarding the ethical recommendation, Al-Qur'an teaches:

"The noblest of you in the sight of Allah is the best of you in conduct" (49:

13). "And fulfil promise, for the promise shall be questioned about" (17:

34). "Righteousness is this that one should believe in Allah . . . and give 
away wealth out of love for Him to the near of kin and the orphans and the needy and the wayfarer and the beggars and for the emancipation of the captives" (2: 17).

In Islam, the term that is most closely related to the term ethics in the Qur'an is khuluq. Al Qur'am also uses a number of other terms to describe the concept of goodness: khair (goodness), birr (truth), qist (equality), 'adl (equality and justice), haqq (truth and goodness), ma'ruf (knowing and approve) and taqwa (piety). Praiseworthy actions are called salihat and despicable actions are referred to as sayyiat (Veithzal, 2012) Ethics is understood as morals or manners which aim to educate human morality. Amin (1995) provides a limitation, that ethics or morals is a science that explains the meaning of good and bad, explains what humans should do to others, states the goals to be directed by humans in their actions and shows the way to do what must be done. Therefore, marketing ethics in Islam is driven by a discipline that avoids the dichotomy between organizations and community interests (Dincer \& Dincer, 2014; Ali \& Al-Aali, 2015). Marketing ethics in Islam is manifested in the form of sharia marketing which, according to Kartajaya \& Sula (2006), as a strategic business discipline that directs the process of creating, offering and changing the value of an initiator to its stakeholders, which in the whole process is in accordance with the contract and the principles of muamalah (business) in Islam.

\section{Islamic Marketing Ethics (IME) Principles}

Koku and Savas (2014) suggest several important principles of Islamic Marketing such as: fairness, equity, respect for consumers / customers, suppliers, and employees; concerns about ethics, human rights and human dignity; concern for the environment, community and neighbors. Abdullah and Ahmad (2010) state that in sharia marketing, in addition to meeting consumer needs and achieving company goals, all related marketing practices such as planning, pricing, distribution and product promotion must conform to the provisions of Islamic sharia. There are nine marketing ethics that become Sharia Marketing principles in carrying out marketing functions (Beekum, 2006; Chaudry, 2012; Kartajaya \& Sula, 2012), namely: have done a comprehensive and inclusive study on Islamic marketing ethics. They have identified four constructs to be the core principles of Islamic marketing:

Tabel 1. Principles of Islamic Marketing

Islamic Marketing Ethics

Landscapes of Islamic marketing:

- Transparency;

- Being respectful to competitors;

- A spiritual-based organization.

\section{Qur'anic Direction}

1) No prejudice (Su'udzhan). Mutual respect for each other is the teachings of the Prophet Muhammad SAW which must be implemented in modern business behavior. One entrepreneur must not discredit other entrepreneurs just for business competition through advertising. Allah SWT says in, QS. Al-Hujurat: 12:"O believers! Stay away from many prejudices, in fact some of the prejudices are sinful, and do not find fault with others, and do not among you who gossip some of the others. Do any of you like to eat the 

disgusted, and believe in Allah, truly Allah is the recipient of repentance, the Most Merciful ".

. 2). No bad-mouth (Ghibah). Ghibah is the desire to destroy people, the glory and honor of others, while they are not in their presence. Usually a marketer is happy when he knows the weaknesses, ugliness and shortcomings of his business opponents. And usually the weakness and the ugliness of the weapons to win the battle in the market by vilifying or defaming business opponents.

Elements of strategic business
architectures:
- Universal market view;
- target customer's heart and soul;
- build a belief system;
- differs self with a good package
of content and context;
- be honest with 4Ps;
- practice a relationship-based
- uselling;
- services ability to transform;
and
- practice a reliable business
process.

1) No cheating. Promises are abilities that have been stated to someone when making an agreement of course based on mutual trust and great responsibility to carry out these promises. The accuracy of the promise can be seen in terms of the timeliness of delivery of goods, the timeliness of payment and carry out something in accordance with the agreed contract.

2) Honesty and Trustworthiness (Amanah). With an attitude of honesty, marketers will be trusted by the buyers but if the marketer is not honest then the buyer will not buy his merchandise. Dishonest traders / marketers will always try to commit fraud on others, as the Qur'an strictly prohibits dishonesty (QS. Al Anfal: 27).

3) Service and humility (Khidmah). Serve attitude is the main attitude of a marketer. Believers are instructed to be generous, polite and friendly when dealing with business partners. A business will always grow and succeed when supported by the best service. For example with friendliness, smiles to consumers will get better business.

Shariah scorecard: create value for stakeholders.
1) Spiritual Personality (Takwa). A trader in running his business must be based on the attitude of piety by always remembering Allah. Awareness of God should be a driving force (driving force) in all actions (Al-Qur'an, At-Taubah: 119)

3. Nice and sympathetic (Shidiq). Good behavior, deeds and courtesy in relationships is the basic foundation and core of good behavior. Al-Qur' an also requires followers to be polite in every way, even in conducting business transactions with fools, a trader must still speak with good words and expressions. 


\begin{tabular}{|c|c|}
\hline Islamic Marketing Ethics & Qur'anic Direction \\
\hline & $\begin{array}{l}\text { 4. Valid and Fair in Business }(A l-A d l) \text {. Islam } \\
\text { supports the principle of justice. In general, } \\
\text { Islam supports all principles in the approach to } \\
\text { justice towards ethics, but in balanced } \\
\text { proportions. Do business fairly, God says. As } \\
\text { written in QS Al An'am: } 152 \text {, "Try to be fair } \\
\text { and you must not act unjustly". Allah loves } \\
\text { those who do justice and hates those who do } \\
\text { wrong, Islam has forbidden every business } \\
\text { relationship that contains wrongdoing and the } \\
\text { obligation to fulfill justice that is applied in } \\
\text { trade relations and business contracts. }\end{array}$ \\
\hline $\begin{array}{l}\text { Shariah marketing enterprise: } \\
\text { - develop an ethical } \\
\text { corporate culture; } \\
\text { - measurement must be clear } \\
\text { and transparent; and } \\
\text { - create a noble cause. }\end{array}$ & $\begin{array}{l}\text { No bribes (Riswah). In sharia, bribery (Riswah) is } \\
\text { forbidden, and bribing is included in the category } \\
\text { of consuming other people's property in a false } \\
\text { manner. Bribery is a grave sin and criminal crime } \\
\text { in a country. Therefore, earning wealth by bribery } \\
\text { is clearly haram. In promoting or advertising it is } \\
\text { not easy to say a promise if the promise cannot be } \\
\text { kept. From Abu Qotadah Al Anshori, the Prophet } \\
\text { sallallaahu 'alayhi wa sallam said:"Be careful with } \\
\text { a lot of swearing in selling merchandise because } \\
\text { he does inherit merchandise, but instead eliminate } \\
\text { (blessing)"(At- Tirmizi). Various advertisements } \\
\text { on television media or on display in print, indoor } \\
\text { and outdoor media, or via radio often provide false } \\
\text { information that violates honesty. Islam as a } \\
\text { whole religion. Rasulullah SAW has provided a } \\
\text { very good example in every business transaction. } \\
\text { He conducts transactions honestly, fairly and } \\
\text { never makes his customers complain, let alone } \\
\text { disappointed. Always keep promises and deliver } \\
\text { merchandise with quality standards in accordance } \\
\text { with customer demand (Kartajaya \& Sula, 2012). }\end{array}$ \\
\hline
\end{tabular}

In summary, it can be concluded that the concept of Islam Marketing is based on three unique principles: (1) value maximization; (2) Shariah compliance; and (3) welfare for all stakeholders.

\section{Green Marketing as the Implementation of Islamic Marketing Ethics}

Green marketing is an activity, set of rules, and a process for creating, communicating, delivering and exchanging offers that have value for consumers, clients, partners and the wider community (Soonthonsmai 2007; Dalstrom, 2013; Ramanakumar, 2012). Social marketing adopts a different perspective and defines green marketing as the development and marketing of products designed to minimize negative effects on the environment. Unlike the retail perspective, social orientation recognizes the cost of pre-consumption and post-consumption with the environment. From these notions it can be concluded that green marketing contains 
several important points, namely: First, the organization or company through its marketing activities, trying to satisfy the needs and desires of consumers; Second, this marketing activity is carried out in a more efficient and effective manner compared to competitors, and Third, this activity has a minimal impact on the destruction of the natural environment so that it can improve the welfare of consumers and society (Ramanakumar, 2012).

Grant (2007) classifies the level of application of green marketing by companies as follows:

1. Green Level. The company began implementing green marketing by setting new standards, and communicating the concept of green marketing value to all members of the organization. This company only has a commercial purpose (where the product, brand, or company image is environmentally friendly).

2. Greener Level. The company began to share social and environmental responsibilities by collaborating with their stakeholders. Companies have green goals and commercial goals (marketing itself achieves green goals, for example changing the way people use products) to become more environmentally friendly.

3. Greenest Level. The company began to innovate by re-establishing culture, creating new lifestyles and new business models that are more environmentally friendly. This study will classify research objects into this category to identify the level of implementation of green marketing.

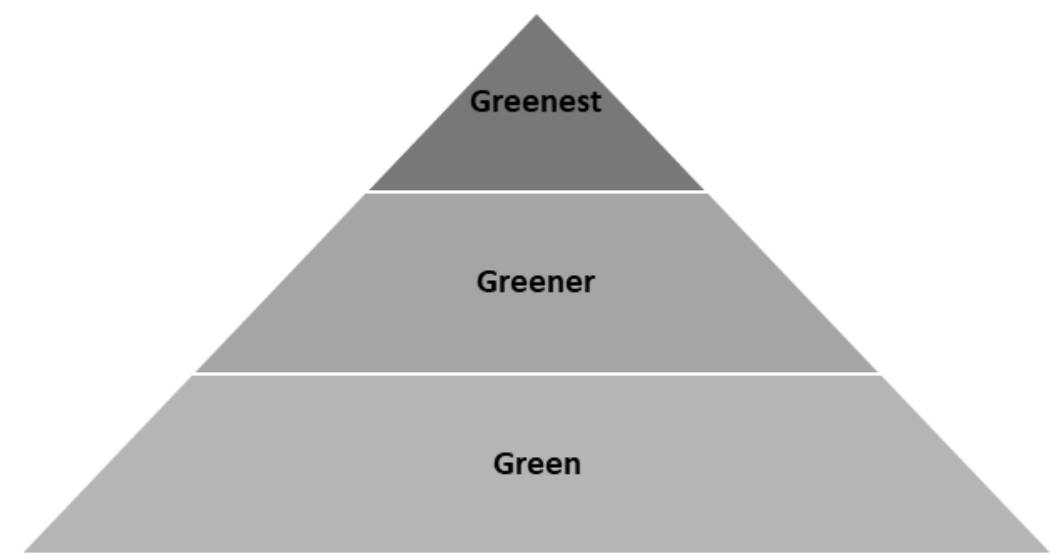

Figure 1. The Level of Green Marketing Activities in Company

\section{Green Marketing Strategy}

There are four types of green marketing strategies that are implemented in companies. Before applying these strategies, companies consider the likely size of the green market in their industry and their ability to differentiate their products on "greenness" from competitors before choosing one of the strategies in the matrix. 


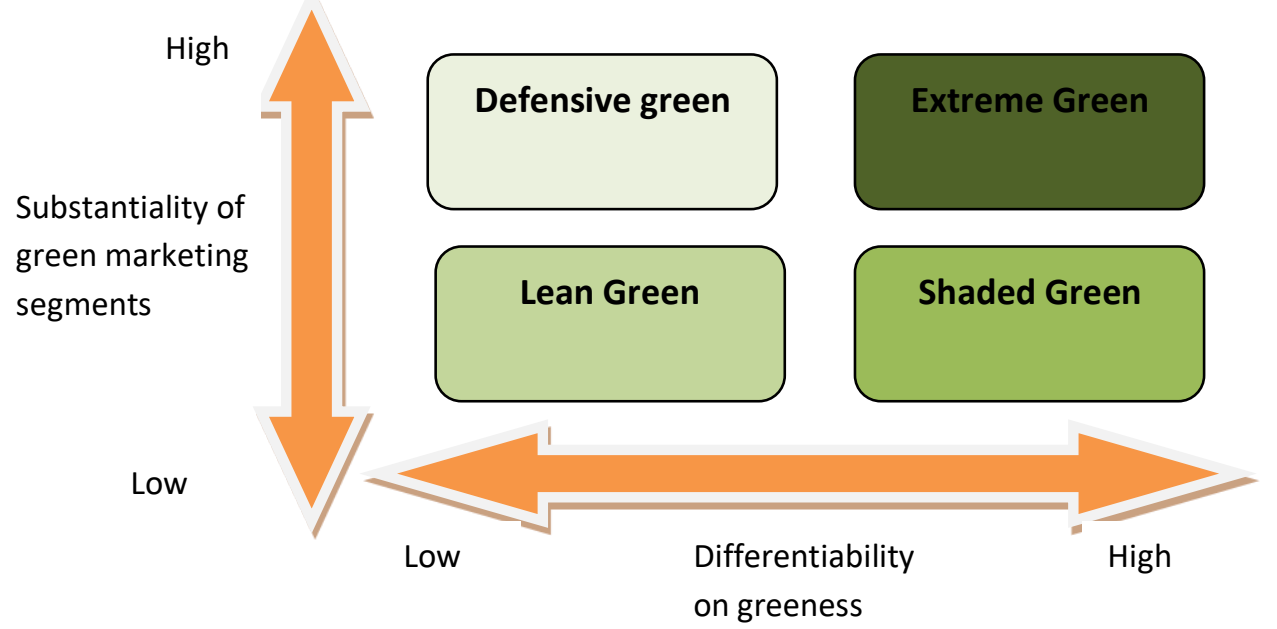

\section{Figure 2. Green Marketing Strategy Matrix Source: Ginsberg \& Bloom (2014)}

1. Lean Green. Lean Greens is a good corporate citizen, but this company does not focus on publicizing or marketing their green initiatives. Instead, they are interested in reducing costs and increasing efficiency through pro-environment activities, thereby creating competitive advantages at lower costs, not environmentally friendly ones. This company likes long-term preemptive solutions and wants to comply with regulations, but they don't see large amounts of money being generated from the green market segment.

2. Defensive green. Defensive Greens uses green marketing as a precautionary measure, responding to crises or responding to competitors' actions. The company strives to improve brand image and reduce damage. Their environmental initiatives may be sincere and sustainable, but their efforts to promote and publicize these initiatives are sporadic and temporary.

3. Shaded Green. Shaded Greens invests in a long-term, broad, environmentfriendly process that requires substantial financial and non-financial commitments. These companies see the green market as an opportunity to develop innovative products and technologies that satisfy the needs that have a competitive advantage. Shaded Greens promotes the direct and tangible benefits provided to customers and sells their green products through the main channels.

4. Extreme Green. Environmental issues are fully integrated into the business and product life cycle processes of these companies. The practice involves a life cycle pricing approach, total quality environmental management, and manufacturing for the environment; green consumers are specially served.

\section{Green Marketing Mix}

Green marketing mix comes from conventional marketing (Kontic et al. 2010). In environmentally friendly marketing, environmental care is an element that must be given by the marketing mix with full accountability. The marketing mix commonly 
known as $4 \mathrm{P}$ consists of components such as products, prices, places and promotions:

Product.The ecological goal in product planning is to reduce resource consumption and save and increase scarce resources. According to the principles of green marketing, every component in the marketing mix will have a green perspective from building to introducing products to the market (Arseculeratne \& Yazdanifard, 2014). Environmentally friendly design products must be manufactured and the packaging process must reduce contamination and pollution. Product upgrades certainly involve a large amount of sunk costs but they are worth solving because product development will bring a turnaround in sales. The reverse logistics method where customers return to business using packaging, packaging and even the recycled product itself will greatly help to preserve the environment (Arseculeratne \& Yazdanifard, 2014).

Price. Price is a critical and important factor of the green marketing mix. Most consumers will only be prepared to pay additional value if there is a perception of additional value products. This value can improve performance, function, design, visual appeal, or taste. Being a green product is really expensive because they consist of various costs such as teaching countries, gadgets, the establishment of modern technology, absorbing extrinsic costs, turning waste into recycled products. Marketing activities must rationalize these expenses and consumers need to be convinced to pay premiums, so realistic messages in advertising are needed (Arseculeratne \& Yazdanifard, 2014).

Place. Choosing how and when to make a product available will have a significant impact on customers. Green distribution consists of appointment channels in a way to reduce environmental damage. Most damage is induced during the shipment of goods. Therefore safety precautions must be applied in the delivery of goods (Arseculeratne \& Yazdanifard, 2014).

Promotion. Business promotion material is needed in environmentally friendly marketing. The main go green information must be transmitted to customers through direct marketing, sales promotion, advertising, and public relations. Public relations and advertising have indeed become the most widely used platform to launch a green business perspective. Green advertising can be used to promote products, justify features and prices (Arseculeratne \& Yazdanifard, 2014).

Based on the theoretical basis above, Figure 4 illustrates the analytical framework in research, in which the writer will identify the level of application of green marketing in the company's philosophy and marketing strategy, then determine the model of green marketing strategy applied and the implementation of marketing strategies in a green marketing mix. 


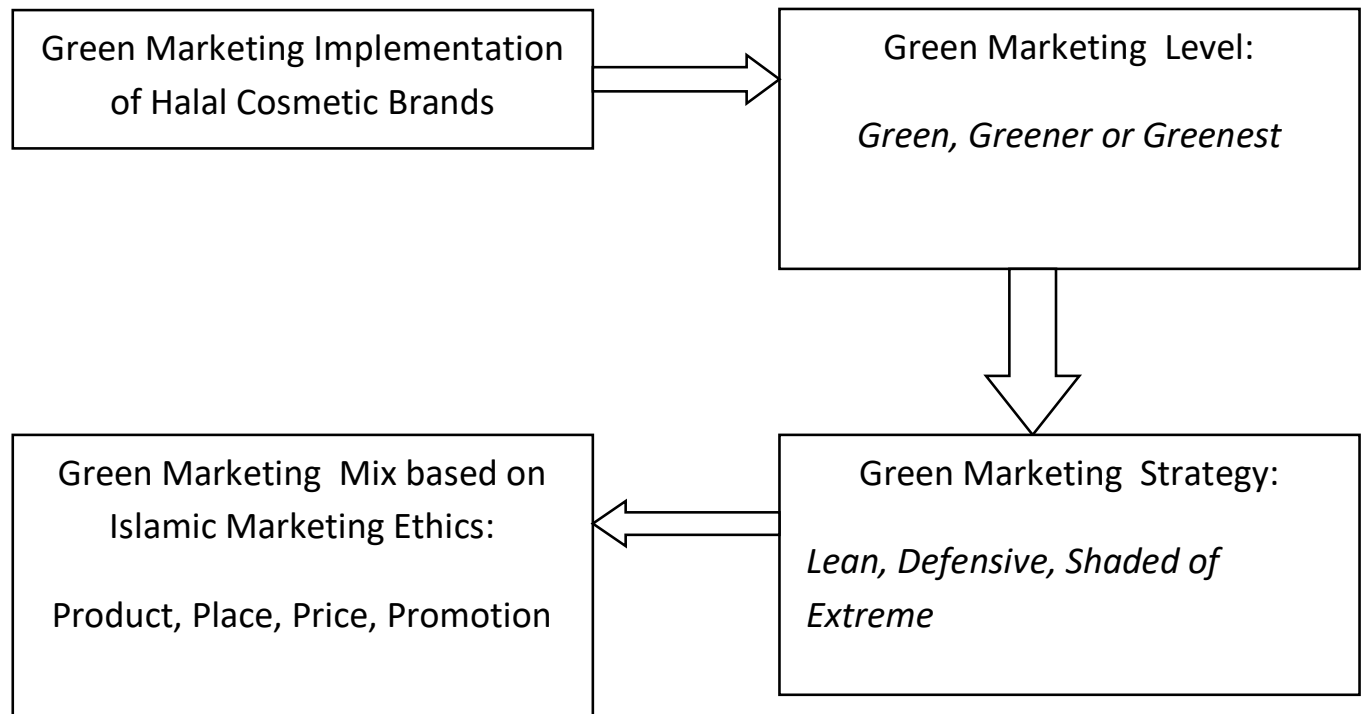

Figure 3. Research Framework

\section{RESEARCH METHODS}

\section{Sample Selection Method}

This case study uses a qualitative research approach that selecting research object based on purposive sampling method. The consideration of selecting halal cosmetic brands are:

1. Have operated more than five years in Indonesia based on published company report data.

2. Earned halal certificate and actively promote their products as halal products based on published company report data.

3. Have been selected by top four halal cosmetic brands in market share and revenue based on Global Business Guide Indonesia (2018).

The data is obtained through literature review, company report, website, media news, and structured online-interview to each marketing manager of selected companies.

The data collected in this study focuses on green marketing strategy in the aspects of marketing goals / value, product strategy, price, place and promotion in halal cosmetics brands. Therefore, the respondents of this study were the marketing managers of the four companies. Online structured interviews were chosen to be sent through corporate email, because of the distance of two companies that headquartered outside Indonesia. The profiles of respondents are all women, aged 35-50 years, having working experience in the company over five years and earned master graduate as educational background.

\section{Data Analysis}

The data was analyzed by the data triangulation and method triangulation. Triangulation is essentially a multimethod approach that researchers take when collecting and analyzing data. The basic idea is that the phenomenon under study 
can be well understood in order to obtain a high level of truth if approached from various points of view (O'Donoghue \& Punch, 2003: Altrichter et al. 2008). Capturing a single phenomenon from different viewpoints allows a reliable level of truth to be obtained. Therefore, triangulation is an attempt to check the correctness of data or information obtained by researchers from different points of view by reducing as much as possible the bias that occurs during data collection and analysis.

1. Method triangulation compares information or data in different ways. This study uses structured online interview, observation, and literature study. Through various perspectives or views, it is hoped that results that are close to the truth will be obtained. Therefore, this stage of triangulation is carried out if the correctness of the data or information obtained from the subject or research informant is doubtful.

2. Data triangulation explores the truth of certain information through various methods and sources of data acquisition. For example, apart from going through interviews and observations, researchers use written documents, archives of company reports, historical documents, official records, personal notes or writings and pictures or photos. These various views will give birth to the breadth of knowledge to obtain reliable truth.

This method is preferable in this study to avoiding bias and to drawing a more detail and balanced picture of phenomenon. The analysis result is presented in inductive explanation to generate ideas (O’Donoghue \& Punch, 2003: Altrichter et al. 2008).

\section{RESULTS AND DISCUSSION \\ Halal Cosmetic Brand Development in Indonesia}

In 2020, the development of the cosmetics and toiletries industry in Indonesia experienced a very significant development, which amounted to $6.6 \%$ with a contribution to the Gross Domestic Product of 7.95 trillion rupiahs (Statista, 2020). Of this rapid growth, nearly $50 \%$ growth was contributed by cosmetic products. Some factors that support this growth are the increasing middle economic groups and affluent consumers towards cosmetic products. In this very potential industry, several halal cosmetics have dominated the market share of more than $50 \%$ (Statista, 2020). This is encouraged by the adoption of Halal Product Assurance Law No.33 2014 which also certifies cosmetics products (GBG, 2014). Because of the very large Muslim population in Indonesia, as a form of adherence to religion, the majority of cosmetics consumers (58\%) are more comfortable using halalcertified cosmetics than non-cosmetics. In fact, they consider the halal certification factor more than price, packaging, and trends (GBG, 2018). On the other hand, the potential market for the halal cosmetic brand is the growth of non-Muslim green consumers who also prioritize products that are not only made from green ingredients but also meet the elements of safety, environmentally friendly, no animal testing and promoting fair trade as the main principles of halal product preparation (Rezai et al. 2012; Mathew, 2014; Ali et al. 2016). This makes the green marketing strategy very relevant to be applied by halal cosmetic brands to create 
positive Muslim consumer perceptions and increase their awareness (syiar) to use halal products as a form of adherence of a Muslim to his religion. Meanwhile, for non-Muslim green consumers, this marketing strategy is very important to increase their awareness in using products that are good, healthy and do not have a negative impact on environmental sustainability.

\section{Green Marketing Level of Halal Cosmetic Brands}

Based on the results of research conducted on four halal cosmetic brands that have marketed their products in Indonesia over the past five years, there are significant differences in the degree of implementation of green marketing strategies, which are summarized in the table below:

Table 2. Summary of Green Marketing Level of Halal Cosmetic Brands

\begin{tabular}{|c|c|c|c|}
\hline Company & Indicators & Examples & Category \\
\hline $\mathrm{W}$ & $\begin{array}{l}\text { The company innovates } \\
\text { by re-establishing } \\
\text { culture, creating new } \\
\text { lifestyles and new } \\
\text { business models that } \\
\text { are more } \\
\text { environmentally } \\
\text { friendly. }\end{array}$ & $\begin{array}{l}\text { - All business processes } \\
\text { models use the principle of } \\
\text { sustainability. } \\
\text { - Green marketing mix. } \\
\text { - Has published an audited } \\
\text { sustainability report. }\end{array}$ & Greenest \\
\hline M & $\begin{array}{l}\text { The company shares } \\
\text { social and } \\
\text { environmental } \\
\text { responsibilities by } \\
\text { collaborating with their } \\
\text { stakeholders. } \\
\text { Companies have green } \\
\text { goals and commercial } \\
\text { goals (marketing itself } \\
\text { achieves green goals, } \\
\text { for example changing } \\
\text { the way people use } \\
\text { products) to become } \\
\text { more environmentally } \\
\text { friendly. }\end{array}$ & $\begin{array}{l}\text { - } 75 \% \text { of their products are } \\
\text { natural-based products. } \\
\text { - Green core values. } \\
\text { - Created active and } \\
\text { collaborative CSR programs } \\
\text { with stakeholders to support } \\
\text { environmentally conscious } \\
\text { campaigns. }\end{array}$ & Greener \\
\hline $\mathrm{S}$ & $\begin{array}{l}\text { The company innovates } \\
\text { by re-establishing } \\
\text { culture, creating new } \\
\text { lifestyles and new } \\
\text { business models that } \\
\text { are more } \\
\text { environmentally } \\
\text { friendly. }\end{array}$ & $\begin{array}{l}\text { - Committed to only produce } \\
\text { green products (natural } \\
\text { based and clinically tested } \\
\text { to be safe and healthy). } \\
\text { - All business processes } \\
\text { models use the principle of } \\
\text { sustainability. } \\
\text { - Green marketing mix. }\end{array}$ & Greenest \\
\hline $\mathrm{Z}$ & $\begin{array}{l}\text { The company } \\
\text { implements green } \\
\text { marketing by setting } \\
\text { new standards, and }\end{array}$ & $\begin{array}{l}\text { - Targeting multisegmented } \\
\text { market (green product and } \\
\text { non-green produuct) }\end{array}$ & Green \\
\hline
\end{tabular}




\begin{tabular}{|c|c|c|c|}
\hline Company & Indicators & Examples & Category \\
\hline & $\begin{array}{l}\text { communicating the } \\
\text { concept of green } \\
\text { marketing value to all } \\
\text { members of the } \\
\text { organization. This } \\
\text { company only has a } \\
\text { commercial purpose } \\
\text { (where the product, } \\
\text { brand, or company is } \\
\text { more friendly image is } \\
\text { more environmentally } \\
\text { friendly, }\end{array}$ & $\begin{array}{l}\text { - Starting to develop plant- } \\
\text { based cosmetics that } \\
\text { claimed to be safe and } \\
\text { healthy }\end{array}$ & \\
\hline
\end{tabular}

Source: Processed by author

Based on product $\mathrm{Z}$ respondents, the company has indeed developed products based on vegan ingredients, but not for all of its products. As stated by respondents that "Our products target many segments, both for green consumers and not. But of course we continue to develop plant-based cosmetics that are safe for all skin types". The commercial goals in implementing green marketing is very strong here, when green marketing is used as a strategy to expand market share. Meanwhile, in M company, almost all of their products use natural-based products, as well as their core values and CSR programs that support collaboration between companies, consumers and governments to support environmentally conscious campaigns. The most comprehensive product in becoming the Greenest is $\mathrm{W}$ and $\mathrm{S}$ products, because the company is not only campaigning about being environmentally conscious, but also campaigning to change the lifestyle of consumers to be more environmentally friendly. Respondents from S products revealed that "We are not only committed to producing products that are clinically tested to be safe and healthy, but all our business processes and models also prioritize the principle of sustainability. We concern about where material is taken from, how to preserve it, how we treat workers who do it and how we improve the welfare of all our distribution channels with profitable shares". Respondents from W brand also added, "although our efforts to become a fully green company are still far from expectations, we must first ensure that our carbon footprint decreases every year, uses more environmentally friendly energy and able to inspire more consumers to reduce plastic waste".

\section{Green Marketing Strategy of Halal Cosmetic Brands}

Based on the collected data, $\mathrm{Z}$ company tends to implement green marketing principles in terms of product development, design and manufacturing. For example, the respondent stated that "Z company has developed natural-ingredientsbased cosmetics that are safe to use for adolescents to adults and do not use materials that are harmful to health such as mercury, hydroquinone, retinoic acid, resorcinol, synthetic dyes, diethylene glycol and lead ". In addition, Z company also began to use cosmetic packaging from recycled materials (returnable packaging) to minimize packaging waste. The $\mathrm{Z}$ manufacturing process also uses the concept of 
environmentally friendly with an industrial sewage treatment system that is ISO 9000 standard and minimizes water consumption.

Table 3. Summary of Green Marketing Mix Strategy of Halal Cosmetic Brands

\begin{tabular}{|c|c|c|}
\hline Company & Indicator & Level \\
\hline W & $\begin{array}{l}\text { Green product, packaging, } \\
\text { manufacturing, "loud and influential" } \\
\text { promotion, place (distributor, retailer) } \\
\text { and pricing }\end{array}$ & Extreme \\
\hline M & $\begin{array}{l}\text { Green product, } \quad \text { packaging, } \\
\text { manufacturing and "quiet" promotion. }\end{array}$ & Defensive \\
\hline S & $\begin{array}{l}\text { Green product, } \\
\text { manufacturing, "loud" promotion and } \\
\text { pricing. }\end{array}$ & Shaded \\
\hline $\mathrm{Z}$ & $\begin{array}{l}\text { Green product, packaging and } \\
\text { manufacturing. }\end{array}$ & Lean \\
\hline
\end{tabular}

Source: Processed by author

However, the $\mathrm{Z}$ company with this Lean Strategy has not yet integrated the other green marketing mix as Defensive Green Strategy implemented by the company $\mathrm{M}$. In addition to also producing green products, packaging and manufacturing, respondents from company $\mathrm{M}$ revealed that "Based on the values adopted by our company that prioritize producing natural Eastern products, we strongly support all campaigns that support environmental sustainability ". The respondent added that "We have collaborated with many parties such as the Ministry of Environment and Forestry for the no plastic bag campaign in product sales transactions at our outlets". Company $\mathrm{M}$ also has a Corporate Social Responsibility that consistently supports the Zero Waste Society by educating the public about Reduce, Reuse, Recycle and donations in the form of trash bins in several places in Indonesia. However, M company acknowledged that their green campaign was not widely known by consumers by the wider community, because it did not include the campaign in the advertisements of their products. This is because M company thinks that the image of natural products, and SPA treatment products that are their superior, is sufficient to show their image as a halal and environmentally friendly product.

Furthermore, $\mathrm{S}$ products in addition to producing products that are claimed to use vegan ingredients, packaging using returned packaging materials, energysaving manufacturing and ISO 22716 (Good Manufacturing Practice), this company also uses an effective promotional strategy with advertising, both in print media, electronics, and online media which primarily through influencers and SEO blogs. Respondents from company $\mathrm{S}$ said "As a form of our responsibility to produce halal, natural and tested products, we need 2 years to develop products". They stated that their products are free from alcohol and gelatine in their aromatic cosmetic products or skin care and no animal testing.

The respondent added that "We openly invite the community to look closely at the process of making our skin care and cosmetics in our factory". This shows the principle of transparency and honesty in accordance with the principles of Islamic 
Marketing Ethics applied by company S. As the only non-Indonesian company that is certified halal cosmetics, $\mathrm{S}$ also has an effective promotion strategy, by collaborating with local cosmetics companies, Kanistri Botanicals which also manufactures cosmetic products from natural ingredients that together promote quality, halal and environmentally friendly products; so as to attract Indonesian consumers.

From this research, which can be categorized as the extreme green strategy is company $\mathrm{W}$. This company employs all marketing mix elements, including setting the green principle for their distributors and retailers. $\mathrm{W}$ is the halal cosmetic manufacturer with the largest market share in Indonesia and is growing in the international market. According to respondents, "Our company tagline, " Halal from the Beginning "has a strong message, which shows that our products are made with ingredients that are safe and healthy for skin; also obtained and processed in halal method ". W brand also emphasized that their products are very customer-oriented, thus providing many choices for almost every type of consumer skin both in Asia and non-Asia. Furthermore, "Our promotion strategy that uses celebrity female who are energetic, independent, from multi-professions and multi-races; shows that our halal products can be used by all, not just Muslim consumers." The message of W in their product is based on the philosophy that Islamic values are rahmatan lil alamin, member rahmat (good for all) as is the verse .... Also, W companies in selecting distributors and retailers, also consider the sharia principles inherent in their brand image. "We are very selective in choosing distributors and retailers of our products. We will make sure our products are also marketed in places that (only) sell our products (which are halal), not mixed with other products that are not yet clear (halal or haram)". However, in determining pricing, W tends to set cross-selling or up-selling pricing because it assumes that $\mathrm{W}$ dares to set premium prices because it believes that its products provide more benefits to its consumers. "Consumers of halal products, more concerned with the halal ingredients and the process of making skin care or cosmetics with halal method, but not too pricesensitive", respondents added. This is certainly a little contrary to the IME value about the suggestion not to take too much profit. However, respondent $\mathrm{W}$ added, "When choosing value-based pricing strategy, we also want to provide a brand image as a quality product, and our intention is to use our profit optimally for developing differentiation of sustainable halal skincare and cosmetics products". 
Ika Diyah Candra: Revisiting Green Marketing Implementation in Halal 301

Cosmetic Brands

\section{Green Marketing Mix of Halal Cosmetic Brands}

Table 4. The Implementation of Green Marketing Mix in Halal Cosmetic Brands

\begin{tabular}{ccccccc}
\hline Company & $\begin{array}{c}\text { Halal } \\
\text { Certificate }\end{array}$ & $\begin{array}{c}\text { Green } \\
\text { Product }\end{array}$ & $\begin{array}{c}\text { Green } \\
\text { Price }\end{array}$ & $\begin{array}{c}\text { Green } \\
\text { Place }\end{array}$ & $\begin{array}{c}\text { Green } \\
\text { Promotion }\end{array}$ & Level \\
\hline W & V & V & V & V & V & Extreme \\
M & V & V & - & - & - & Defensive \\
S & V & V & V & - & V & Shaded \\
Z & V & - & - & - & - & Lean \\
\hline
\end{tabular}

Source: Processed by author

Based on the previous explanation, the companies which are the objects of this research can be classified based on their green marketing strategy. Furthermore, the implementation of the marketing strategy is manifested again into the marketing mix which is expected to be able to change consumer behavior so as to reduce the negative impact of artificial products on the environment (Delafrooz, Taleghani, \& Nouri, 2014).

In product aspects, the four companies have used one of the main green marketing tools, namely eco-label. According to respondents $\mathrm{W}, \mathrm{M}, \mathrm{S}$ and $\mathrm{Z}$, their company uses eco-labels to make it easier for consumers to understand how a product is made. Labels are made in the form of serial numbers made from paper, with complex diagrams that are an important part of the packaging of a product. Labels can include product brands or serial numbers that indicate certain information. They add that, this eco-label makes it easy for consumers to easily distinguish between environmentally friendly products and other standard products. The introduction of eco-labels has a positive impact on the delivery of information about green products and consumers' desire to buy. Another aspect of the product is the green brand. The four products together embed brands that use the words "natural", "pure", "clean", "purifying" in some of their product brands as forming the image of products made from natural ingredients and safe for skin health. S product manufacturers reveal that eco-brands must be used to show the situation that green products function the same as non-green ones but provide more benefits. This brand equity is very effective in influencing consumer emotions. In Islam, the use of a good name is also recommended, both for member names of children, places of business and even products, as stated, "And do not commit abuse on the Earth, spreading corruption" (Qur'an 2:60) and elsewhere. "And do not desire corruption in the land, Indeed, God does not like corruptors" (Qur'an 28:77).

In the place aspect, the four companies also have similarities in determining the location of their stores / retailers, who pay attention to marketing principles such as proximity to target markets and attention to business competition. This is following Islamic Marketing Ethics which states that "In fact, what is halal is clear, just as what is haram is clear. Between the two there is the case of syubhat - which is still vague - which is unknown to most people. Whoever avoids the case of syubhat, then he has saved his religion and honor. Whoever falls into a syubhat case, then he can fall into a haram case... " (HR. Bukhari no. 2051).

Furthermore, in the aspect of price, there are some striking differences regarding the pricing standard. S and $\mathrm{M}$ tend to use economic prices while $\mathrm{W}$ and 
$\mathrm{Z}$ use premium prices. Although it is not implicitly promoted as a halal-certified product, $\mathrm{M}$ products apply the principle of pricing more sharia than the two brands that have Islamic nuances (not profit maximization oriented) as quoted by $\mathrm{Al}$ Quran, 2: 279: "Deal not unjustly, and you shall not be dealt unjustly. ' However, certainly the consideration of pricing associated with target markets, brand equity and the transaction that mutually agreed by sellers and customer cannot also be ignored in determining whether cosmetics brands have established green marketing as well as Islamic Marketing Ethics or not. This statement is supported by (Qur'an, An-Nisa:29) that stated, "Believers! Do not devour one another possessions wrongfully, rather, let there be trading by mutual consent, and do not kill yourselves. Surely Allah is ever compassionate to you". Therefore, as long as the consumer able to buy the products without being enforced, there is no reason to forbid it. This is also supported by Ibn Maajah, 2340 that stated, "There should be neither harming nor reciprocating harm".

Finally, in the aspect of promotion, the four companies together expressed the importance of delivering product promotion materials honestly, transparently, and not exaggerating the facts that manifested Shidiq, Amanah and Fathonah principle in IME. Respondents from company $\mathrm{S}$ revealed that "our company is very open to company visits, because what we promote as halal products is appropriate as we always apply in the manufacturing process". Respondents from company W also stressed that "we provide specialized training to our sales force, on how to sharply promote products. For example, using our hijab and uniform are polite and closed; and polite ways of promoting and listening to consumers ". In addition, electronic and online advertising materials are also a concern of $\mathrm{W}$ products, which have never placed non-mahram men and women in the advertising of their products This rule inspired by sharia rule as stated by:

"Say to the believing men that they cast down their looks and guard their private parts; that is purer for them; surely Allah is Aware of what they do. And say to the believing women that they cast down their looks and guard their private parts and not display their ornaments except what appears there of, and let them wear their head-coverings over their bosoms, and not display their or name except to their husbands..." (Al-Qur'an, 24:30-31).

\section{CONCLUSION}

The results of the study concluded that among the top four halal cosmetics brands studied, two brands had implemented the concept of green marketing strategy comprehensively (shaded green and extreme green), while the other two brands applied lean green and defensive green marketing strategy and implementation. It means that not all halal cosmetic brands are able to implement marketing strategy comprehensively in their marketing mix.

The similarity of the four brands in implementing marketing strategy through product, place, price and promotion mix is their ability to apply green marketing principles that use natural, environmentally friendly product ingredients, do not use prohibited substances such as alcohol and glycerin from lard and not conduct animal testing which is also in accordance with the principle of halal products according to Islam. 
However, the difference in pricing strategy makes the two companies categorized to apply more green marketing strategy with premium pricing than Islamic Marketing Ethics which prioritizes inexcessive profit taking. In the aspect of promotion, the four companies alike expressed the importance of conveying promotional products honestly, transparently and not in excess of the facts. These values are also in accordance with Islamic Marketing Ethics, especially the principles of Adl and Amanah.

The limitation of this research lies in the perspective of researchers who are more corporate mindset, not consumer mindset in analyzing the implementation of marketing strategies. For further research, the authors suggest using a consumer mindset to evaluate the effectiveness of green marketing strategies in influencing consumer behavior and their purchasing decisions. Finally, this research is expected to provide scientific benefits for the development of Islamic Marketing studies and green marketing studies in the context of practical business; provide managerial input for halal cosmetic brands to increase the effectiveness of their marketing strategies to expand the market and attract more consumers and the value of their products, and provide insight to halal cosmetic brands consumers to be more critical in knowing company values and adding product knowledge before they buy Halal products.

\section{REFERENCES}

A, Ahmad. (1995). Business Ethics in Islam, International Institute of Islamic Thought (IIIT), Virginia, USA, p- 28.

Abdullah, Kalthom. (2008). Marketing mix from an Islamic perspective. Petaling Jaya: Prentice Hall.

Abdullah, K. and Ismail Ahmad, M. (2010). Compliance to Islamic marketing practices among businesses in Malaysia. Journal of Islamic Marketing, Vol. 1 No. 3, pp. 286-297.

Abzari, M., Safari Shad, F., Abedi Sharbiyani, A. A., \& Parvareshi Morad, A. (2013). Studying the effect of green marketing mix on market share increase. European Online Journal of Natural and Social Sciences: Proceedings, $2(3$ (s)), pp-641.

Afzal-ur-Rahman, M. A. (1975). Economic doctrine of Islam (Vol. 11). Lahore: Islamic Publication Ltd.

Ahmad, S. F. (1991). The ethical responsibility of business: Islamic principles and implications. Journal of objective studies, 3(1), 23-43.

Al-Bukhari, M. (1978). Sahih al-Bukhari. Dar Ul-Hadith.

Ali, A. (2001). Al-Qur'an. Princeton University Press.

Ali, S., Halim, F., \& Ahmad, N. (2016). Beauty premium and halal cosmetics industry. Journal of Marketing Management and Consumer Behavior, 1(4). pp. 52-63.

Altrichter, H., Feldman, A., Posch, P. \& Somekh, B. (2008). Teachers investigate their work; An introduction to action research across the professions. Routledge (2nd edition).

Arifin, Johan. (2009). Etika Bisnis Islami, Semarang: Walisongo Press. 
Arseculeratne, D., \& Yazdanifard, R. (2014). How green marketing can create a sustainable competitive advantage for a business. International business research, 7(1), 130. : http://dx.doi.org/10.5539/ibr.v7n1p130

Asyraaf, Muhammad Dawwabah. (2007). Bisnis Rasulullah. Semarang: Pustaka Nuun.

At-Tirmidzi, A. I. M. B. (2013). Isa. Ensiklopedia Hadits 6; Jami’at-Tirmidzi.

Beekum, Rafik Issa. (2006). Etika Bisnis Islami . Pustaka Belajar.

Bukhari, S. A. A., Hashim, F., Amran, A. B., \& Hyder, K. (2019). Green Banking and Islam: two sides of the same coin. Journal of Islamic Marketing.

Chan, E. S. (2013). Managing green marketing: Hong Kong hotel managers' perspective. International Journal of Hospitality Management, 34, 442-461, https://doi.org/10.1016/j.ijhm.2012.12.007

Chaudhry, Muhammad Sharif. (2012). Sistem Ekonomi Islam, Jakarta; Kencana Predana Media Group.

Chin, C. H., Chin, C. L., \& Wong, W. P. M. (2018). The implementation of green marketing tools in rural tourism: the readiness of tourists?. Journal of Hospitality Marketing \& Management, 27(3), 261-280, https://doi.org/10.1080/19368623.2017.1359723

Chin, J., Jiang, B. C., Mufidah, I., Persada, S. F., \& Noer, B. A. (2018). The investigation of consumers' behavior intention in using green skincare products: a pro-environmental behavior model approach. Sustainability, 10(11), 3922, https://doi.org/10.3390/su10113922.

Dalstrom, M. (2013). Shadowing Modernity: The Art of Providing Mexican Healthcare for Americans. Ethnos, Vol. 78, pp. 75-98, available at: https://doi.org/10.1080/00141844.2012.688760.

Davari, A., \& Strutton, D. (2014). Marketing mix strategies for closing the gap between green consumers' pro-environmental beliefs and behaviors. Journal of Strategic Marketing, 22(7), 563-586, https://doi.org/10.1080/0965254X.2014.914059

Departemen Agama.. (2008). Tafsir dan Terjemahan Lengkap Al Qur'an 30 Juz. Jakarta: Kementrian Agama Republik Indonesia.

Delafrooz, N., Taleghani, M., \& Nouri, B. (2014). Effect of green marketing on consumer purchase behavior. QScience Connect, 2014(1), 5, https://doi.org/10.5339/connect.2014.5

Dincer, C., \& Dincer, B. (2014). An Overview and Analysis of Marketing Ethics. International Journal of Academic Research in Business and Social Sciences, 4(11), 151-158, : http://dx.doi.org/10.6007/IJARBSS/v4-i11/1290

Ginsberg, J. M., \& Bloom, P. N. (2004). Choosing the right green marketing strategy. MIT Sloan management review, 46(1), 79-84.

Global Business Guide Indonesia. (2014).Halal Implementing regulation: Where are they now?. Retrieved from http://www.gbgindonesia.com/en/main/legal_updates/halal_implementing_r egulations_where_are_they_at_now.php

Global Business Guide Indonesia. (2018). Indonesia's Cosmetics Industry: The Rise of Halal Cosmetics. Retrieved from http://www.gbgindonesia.com/en/manufacturing/article/2018/indonesia_s_c 
Ika Diyah Candra: Revisiting Green Marketing Implementation in Halal 305 Cosmetic Brands

osmetics_industry_the_rise_of_halal_cosmetics_11842.php

Grant, John. (2007). The Green Marketing Manifesto. John Wiley \& Sons, Ltd., West Sussex, England.

Hasan, Ali. (2009). Manajemen Bisnis Syariah . Yogyakarta: Pustaka Pelajar.

Hassan, A., Chachi, A., and Latiff, S. A. (2008). Islamic Marketing Ethics and Its Impact on Customer Satisfaction in the Islamic Banking Industry. J.KAU: Islamic Economics, 21(1), 23-40

Hassan, M. H., Hosseinpour, M., Nezakati, H., \& Jofreh, M. (2015). Highlighting Influential Factor to Inculcate Green Behaviour. Journal of Applied Sciences, 15(3), 405-410., https://scialert.net/abstract/?doi=jas.2015.405.410

Ishak, M. Abdullah, O. (2012). Islamic Perspective on Marketing Mix. International Journal of Business and Management Studies, 4 (1), 121-131. Retrieved from https://dergipark.org.tr/en/pub/ijbms/issue/26066/274647

Islam, T., \& Chandrasekaran, U. (2013). Halal marketing: Growing the pie. International Journal of Management Research and Reviews, 3(12), 3938.

Kamali, M. H. (2012). Environmental Care in Islam: A Quranic Perspective. Islam and Civilisational Renewal (ICR), 3(2), http://www.aalalbayt.org/EnvConference/002.pdf

Ya'Qub, H. (2003). Etos kerja Islami: petunjuk pekerjaan yang halal dan haram dalam syari'at Islam. Pedoman Ilmu Jaya.

Kartajaya, Hermawan \& Sula, Muhammad Syakir. (2006). Syariah Marketing. Jakarta; MIZAN.

Kontic, I., \& Biljeskovic, J. (2010). Greening the marketing mix: A case study of the Rockwool Group, http://www.divaportal.org/smash/get/diva2:329044/FULLTEXT01.pdf

Lu, L., Bock, D., \& Joseph, M. (2013). Green marketing: what the Millennials buy. Journal of Business Strategy, 34(6), 3-10, https://doi.org/10.1108/JBS-05$\underline{2013-0036}$

Manjunath, G. and Manjunath, Gundupagi, Green Marketing and Its Implementation in Indian Business Organizations (July 1, 2013). Asia Pacific Journal of Marketing \& Management Review, Vol. 2 (7), July 2013. Available at SSRN: https://ssrn.com/abstract=3057932

Matthew, V. N. (2014). Acceptance on halal food among non-Muslim consumers. Procedia-Social and Behavioral Sciences, 121, 262-271, https://doi.org/10.1016/j.sbspro.2014.01.1127

Mendleson, N. and Polonsky, M. (1995), "Using strategic alliances to develop credible green marketing", Journal of Consumer Marketing, Vol. 12 No. 2, pp. 4-18. https://doi.org/10.1108/07363769510084867

Mohiuddin, M. G., \& Haque, M. S. (2012). Behaving ethically: An essence of Islamic marketing system. European Journal of Business and Management, 4(16), 34-44.

Nashiruddin Al-Albani, Muhammad. (2007). Shahih Sunan Ibnu Majah Buku 2. Jakarta: Pustaka Azzam.

O'Donoghue, T., Punch K. (2003). Qualitative Educational Research in Action: Doing and Reflecting. Routledge. 
Osman, A., Othman, Y. H., Salahudin, S. N., \& Abdullah, M. S. (2016). The awareness and implementation of green concepts in marketing mix: A case of Malaysia. Procedia Economics and Finance, 35, 428-433, doi: 10.1016/S2212-5671(16)00053-8

Ottman, J. A., Stafford, E. R., \& Hartman, C. L. (2006). Avoiding green marketing myopia: Ways to improve consumer appeal for environmentally preferable products. Environment: Science and Policy for Sustainable Development, 48(5), 22-36, https://doi.org/10.3200/ENVT.48.5.22-36

Ramanakumar, K.P.V., Manojkrishnan, C.G, \& Suma, S. R. 2012. Consumer Attitude Towards Green Products of FMCG Sector: An Empirical Study. International Journal of Research In Commerce \& Management, Vol 3 (2), 34-38

Rezai, G., Mohamed, Z. and Nasir Shamsudin, M. (2012), "Non-Muslim consumers' understanding of Halal principles in Malaysia", Journal of Islamic $\begin{array}{llllll}\text { Marketing, } & \text { Vol. } & 3 & \text { No. } & 1, & \text { pp. }\end{array}$ https://doi.org/10.1108/17590831211206572

Saeed, M., Ahmed, Z.U. \& Mukhtar, S. International Marketing Ethics from an Islamic Perspective: A Value-Maximization Approach. Journal of Business Ethics 32, 127-142 (2001). https://doi.org/10.1023/A:1010718817155

Saxena, S. (2015). Are they really green: flipping the second side of green marketing coin-a critical analysis using selected cases. Amity Global Business Review, 10(4), 110-113.

Sergius Koku, P. and Savas, S. (2014). On corporate social responsibility and Islamic marketing. Journal of Islamic Marketing, Vol. 5 No. 1, pp. 33-48.

Soonthonsmai, V. (2007, June). Environmental or green marketing as global competitive edge: Concept, synthesis, and implication. In EABR (Business) and ETLC (Teaching) Conference Proceeding, Venice, Italy.

Statista. (2020). Beauty and Personal Care. Retrieved from < https://www.statista.com/outlook/70000000/120/beauty-personalcare/indonesia>

Susanti, V. (2014). Green Marketing: a Review From Islamic Marketing Ethics Perspective. $\quad$ ASAS, 6(1). pp.106-116, https://doi.org/10.24042/asas.v6i1.1711

Sustina. (2003). Perilaku Konsumen dan Komunikasi Pemasaran. Bandung: PT. Remaja Rosdakarya.

Veithzal, Rivai. (2012). Islamic Business and Economic Ethics, Bumi Aksara.

Wilson, J.A. (2012), "The new wave of transformational Islamic marketing: reflections and definitions", Journal of Islamic Marketing, Vol. 3 No. 1, pp. 5-11.

Wilson, J.A. and Grant, J. (2013), "Islamic marketing-a challenger to the classical marketing canon?", Journal of Islamic Marketing, Vol. 4 No. 1, pp. 7-21

Yusoff, M. (2019). Islamic-Based Relationship Marketing: An Integration of Internal and External Marketing. In Islamic Development Management (pp. 173-183). Springer, Singapore. 